\title{
The Guardianship Council and public policy for children and adolescents
}

\author{
HeMERSON LUIZ PASE ${ }^{1}$ \\ GABRIELE PADILHA CUNHA ${ }^{2}$ \\ MÁRCIA LEITE BORGES ${ }^{1}$ \\ ANa Paula Dupuy Patella ${ }^{3}$

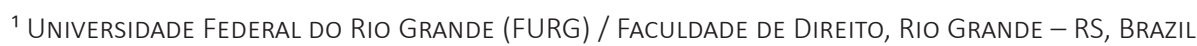 \\ 2 Universidade federal de Pelotas (UfPel) / Instituto de Filosofia, Sociologia e Política, Pelotas - RS, Brazil

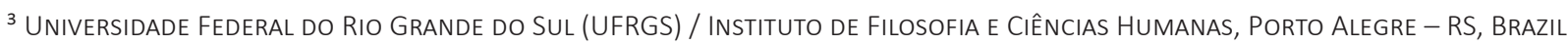

\begin{abstract}
The protection system for children and adolescents was standardized in Brazil based on the Federal Constitution, the Child and Adolescent Statute, and the Guardianship Council. This article aims to analyze the role of the Guardianship Council in consolidating the protection and enforcement of the rights of children and adolescents in the municipality of Pelotas. Partially proven hypotheses state that the Guardianship Council has the protective and educational role in the absence of parents or family members. However, the isolation and fragmentation of the protection system, as well as the reactive posture of counselors and the lack of infrastructure at work make it difficult for the policy to be effective. Qualitative analysis and the primary information was obtained through in-depth interviews.
\end{abstract}

Keywords: Public policy. Childhood and youth. Guardianship Council.

\section{O Conselho Tutelar e as políticas públicas para crianças e adolescentes}

\section{Resumo}

O sistema de proteção à criança e ao adolescente foi normatizado no Brasil com a promulgação da Constituição Federal, a criação do Estatuto da Criança e do Adolescente (ECA), bem como do Conselho Tutelar. Neste trabalho, analisa-se o papel do Conselho Tutelar na consolidação da proteção e da fiscalização dos direitos de crianças e adolescentes no município de Pelotas. As hipóteses parcialmente comprovadas afirmam que o Conselho Tutelar tem o protagonismo protetivo e educativo quando da ausência ou omissão dos pais ou familiares. Todavia o isolamento e fragmentação do sistema de proteção, além da postura reativa dos conselheiros e a falta de infraestrutura no trabalho dificultam a efetividade da política. A estratégia metodológica baseou-se na análise qualitativa, e as informações primárias foram obtidas com o auxílio da técnica da entrevista em profundidade.

Palavras-chave: Políticas Públicas. Infância e Juventude. Conselho Tutelar.

\section{El Consejo Tutelar y políticas públicas para niños y adolescentes}

\section{Resumen}

El sistema de protección para niños y adolescentes fue estandarizado en Brasil con base en la Constitución Federal, el Estatuto del Niño y del Adolescente y el Consejo Tutelar. Este documento tiene como objetivo analizar el papel del Consejo Tutelar en la consolidación de la protección y la observancia de los derechos de los niños y adolescentes en el municipio de Pelotas. Las hipótesis parcialmente probadas indican que el Consejo Tutelar tiene el papel protector y educativo en ausencia u omisión de los padres o familiares. Sin embargo, el aislamiento y la fragmentación del sistema de protección, así como la postura reactiva de los consejeros y la falta de infraestructura en el trabajo dificultan la efectividad de la política. La estrategia metodológica se basó en el análisis cualitativo y la información primaria se obtuvo a través de la técnica de entrevista en profundidad.

Palabras clave: Políticas públicas. Infancia y juventud. Consejo Tutelar. 


\section{INTRODUCTION}

After the time where Brazil lived under its military dictatorship authoritarianism, at the moment of the emergence of redemocratization, there was great hope that, alongside the return of democracy and democratic institutions, there would be a consolidation of citizenship for all Brazilians. This expectation also developed concerning the rights of Brazilian children and adolescents, given that the Federal Constitution promulgated in 1988 (FC/88) started to fully guarantee the protection and enforcement of these rights, raising this portion of society to a citizen status.

Until the coming of this legislation, children and adolescents were considered only as an extension of their parents, to whom they belonged and, often, as a free labor force. The context was one of total social abandonment by the State. Children and adolescents were exposed to violations by the most varied sectors of society, even by their own family.

On July 13, 1990, the Statute of the Child and Adolescent (SCA) was approved at the National Congress, a result of the claims made by non-governmental organizations that defend childhood and youth's rights, alongside the pressure from exogenous organizations such as the United Nations, in the Convention on the Rights of the Child (1989).

With the approval of the SCA, the municipalities became central actors in the implementation of public policies for assistance and protection to children and adolescents. As a result, the Conselhos Tutelares (Guardianship Councils) were created, the public agency responsible for supervising and coordinating a network of public policies aimed at protecting childhood and youth's rights.

The present work aims to understand the peculiarities and the tasks performed by guardianship councilors. Therefore, the following question was raised: what is the role of the Guardianship Council in consolidating the protection and inspection of childhood and youth's rights in the municipality of Pelotas?

The hypothesis presented is that the Guardian Council carries a central potential in the system of protection of children and youth, as it assumes the protective and educational role in the absence or omission of parents or family members. However, it is unable to achieve its objective due to the isolation and fragmentation of the protection system and, also, the reactive posture of the councilors and the lack of infrastructure at work.

The qualitative methodology was chosen to test the hypothesis. Therefore, a bibliographic research was made, as well as an analysis for the pertinent legislation, in order to build a consistent theoretical framework, which would enable the identification of the Guardianship Council's contribution to the protection of children and youth in the country. Moreover, aiming to parallel the legal responsibilities of the Guardianship Council with the daily life lived by the councilors in the city of Pelotas/RS, in-depth interviews with 12 (twelve) councilors were conducted in December 2016 and January and February 2017, in order to investigate the peculiarities concerning the implementation of actions under their responsibility.

\section{Public policies for Children and Youth}

Until the advent of $\mathrm{FC} / 88$ and ECA, children and adolescents were treated by the State as an extension of their parents (COSTA, 1993a). According to González (2015, p. 26):

[...] from the 1920 s to the late 1980 s the Brazilian legislation applicable to children and adolescents (or minors, according to the name of the time) was governed by the binomial abandoned/infrator. Two codes of minors - from 1927 and 1979 respectively - stand out, in addition to numerous sparse laws, of which the one that created the National Policy for the Welfare of Minors - PNBEM, in 1964, in the wake of which the FEBEMs ${ }^{1}$ were created in the 1970s, can be highlighted.

The brazilian State, throughout its history, referred to these as "minors". It did not take care for their most essential rights, such as the right to a dignified life, in a healthy family environment that would contribute to their development. Children were abandoned by their parents; exposed, in their own family, to the most diverse forms of physical, emotional and sexual violence, without any punishment. Parents had complete control over their children, so that the violation of their rights was treated as belonging to the private sphere.

\footnotetext{
${ }^{1}$ State Foundation for the Welfare of Minors. The "minors" in irregular and abandoned situations were treated with rigidity and internal discipline in these institutions, which had its doors closed to society, being surrounded by very high walls, which made ineffective the premise of protection, education and assistance that should be their central objectives (COSTA, 1993b).
} 
The demand for the protection of children and youth's rights to enter the public policy agenda in Brazil was a process that began more than a decade before the enactment of the 1988 Constitution. Thus, inspired by the UN's project of Convention on the Rights of the Child, in 1986, non-governmental organizations of defense of the rights of children and youth began to foment a movement for the protection measures to enter the FC/88. González (2015) states that:

[...] in the period of the National Constituent Assembly two political articulations emerged. The Children and Constituent Commission was created in 1986 by President José Sarney, by UNICEF's suggestion, bringing together several ministries and non-governmental entities such as the $O A B^{2}, C N B B$, the Brazilian Society of Pediatrics, the World Organization for Early Childhood Education (OMEP), and the National Federation of Journalists (FENAJ). It held its first seminar in October 1986; organized a popular amendment (Amendment No. 64) presented to the National Constituent Assembly (POERNER, 1987), as well as the National Priority Child Campaign, organized by the National Movement of Boys and Girls of the Street and Pastoral of the Minor, among others, which proposed the popular amendment 096, collecting signatures. These amendments were later merged, leading to the proposed wording of article 227 of the Federal Constitution (GONZÁLEZ, 2015, p. 29).

With the promulgation of the Citizen Constitution, specifically through article 227, the duties of the State, family and society in protecting the rights that grant citizenship to children and adolescents in Brazil were defined (BRASIL, 1988). In addition, the Federal Constitution established priority for this public in the creation and implementation of public policies.

The Bill that regulated article 227 of the FC/88 and elaborated the SCA entered the National Congress in June 1989, being approved in June 1990 and sanctioned on October 13, 1990. With the enactment of SCA, the Minors' Code (Law No. 6.697/1979) was expressly revoked, which was based on the paradigm of the minor in an irregular situation, that is, it sought "[...] to assist the undervalued, offenders and abandoned, seeking ways to correct the supposed causes of the 'misalignments' of minors" (MOURA, 2016, p. 3).

The SCA attributed to all society and the State the obligation of priority treatment for the protection of rights and effective citizenship of Brazilian children and adolescents. This legislation generated a reorganization of institutions, such as the creation of the Brazilian Center for Childhood and Adolescence Foundation (CBIA), replacing the National Foundation for the Welfare of Minors (FUNABEM), and with the objective of building public policies for the area, encouraging the creation of Councils for the Rights of Children and Adolescents, Guardianship Councils and state and municipal social protection networks.

Facing the creation of this legislative base, anchored in the doctrine of integral protection of children and adolescents, a new task has been assigned to Brazilian society in the defense of children's rights, that of changing the practices and culture, both of the host institutions and society in general, as well as to the tolerance of the use of violence and disrespect for the rights of children and adolescents, especially the most socioeconomically vulnerable (GONZÁLEZ, 2015).

\section{The Child and Adolescent Protection System}

The adoption by the Brazilian State of the doctrine of integral protection for children and adolescents, with the creation of SCA, radically changed the panorama of public policies aimed at this portion of the Brazilian population.

According to the doctrine of integral protection, children and adolescents in Brazil were considered developing people and subjects of a range of rights that should be guaranteed by the State and the entire society. Thus, the development of these subjects would occur with full security, through access to all resources for the consolidation of their citizenship, contrary to the doctrine previously adopted, which foresaw the intervention of the State only when children and adolescents were victims of abandonment or performed any infraction act.

This legislation determined a new responsibility for states and municipalities in the creation and implementation of public policies that would guarantee the effectivation of citizenship and protection against the violation of the rights of children and youth. Several institutions were established, such as the Councils for the Rights of the Child, the Guardianship Councils, the Funds for the Rights of the Child and Public Civil Action.

The SCA, for example, reinforced the responsibility of the Judiciary in the defense of the rights of children and youth with the actions of state Public Ministries, which now had specialized prosecutors, as well as the State Courts of Justice, with the use of specialized courts for the defense and enforcement of rights.

${ }^{2} \mathrm{OAB}$ is the Brazilian equivalent of a Bar Association or Bar Council in English-speaking countries. 
Likewise, the SCA signaled the decentralization of public policies, through which Brazilian states and municipalities should implement a social protection network, articulating several State institutions and actors for the defense of children and youth's rights through the creation and implementation of such policies destined to total protection. It also determined that this public should always be prioritized when creating and implementing public policies, so that it may have protection against violations and be guaranteed full citizenship and opportunities for personal and professional development.

Therefore, the process of creating and implementing public policies and institutions for the defense and protection of citizenship and the rights of children and adolescents by municipalities and states began. CBIA encouraged the creation of Guardianship Councils and Councils for Children and Adolescents in the states and municipalities. The purpose of this foundation was "[...] to formulate, normalize and coordinate, throughout the country, the Policy for the Defense of the Rights of Children and Adolescents, as well as to provide technical assistance to organs and entities that implement this policy" (BRASIL, 1994, art. 3). It was extinguished, however, at the beginning of the Fernando Henrique Cardoso government, which led to the end of financial incentive to states and municipalities for the creation and operation of these institutions (GONZÁLEZ, 2000).

It must be emphasized that some of the states and municipalities managed to create the suggested Councils, but did not put them into operation. In other cases, the Councils came into operation, but they did not have real attributions and capacities to make citizenship effective and protect the rights of children and youth.

\section{The Councils}

The FC/88 grounded the performance of government actions and policies in the area of social assistance. In article 204, the organization of this area is presented:

I - [...] the coordination and the general rules being incumbent upon the federal sphere, and the coordination and implemen- tation of the respective programmes, upon the state and municipal spheres, as well as upon benevolent and social assistance entities;

II - participation of the population, by means of organizations representing them in the formulation of policies and in the control of actions taken at all levels (BRASIL, 1988, art. 204).

As it can be observed, the objective was to carry out the decentralization of actions and simultaneously stimulate popular participation; thus, the popular councils would have the potential to apply the doctrine of integral protection in the sphere of children and youth's rights (CARDOZO, 2011).

It is known that the both the Councils for the Rights of Children and Adolescents and the Guardianship Council have come to assemble the concept of population participation in social protection policies, uniting the concepts of participation and integral protection (CARDOZO, 2011). They are, therefore, instruments for the development of social policies and for the integral protection of children and adolescents at all levels, especially at the municipal level.

The Guardianship Councils are mediating bodies in the policies of assistance to children and adolescents acting in an executive way in the fiscalization and collection of the good functioning of the municipal protection network:

[...] the combination of these precepts to another one that affirms that one of the objectives of social assistance is to support needy children and adolescents (BRASIL, 1988, art. 203), besides the social gravity of the helplessness of poor children and adolescents in the country, perhaps explains the deep articulation that, in practice, exists in the implementation of social assistance policies and the protection and promotion of children and adolescents' rights. The mechanisms created to build this policy were inspired by the institutional design of social assistance (1990a). The Statute foresees the "municipalization of assistance" (1990a, art. 88), as well as the creation of Councils for the Rights of Children and Adolescents and Funds national, state and municipal - through which the resources destined for this policy will be administered. The primary functions of the councils are to supervise the application of the fund's resources, in each sphere of public administration, and to supervise the elections and functioning of the Guardianship Council. Unlike the area of social assistance, in this case there is the Guardianship Council, which is the executor of the policies, acting in articulation with public administrators, the Public Ministry, and the Judiciary in the protection of rights. As in social assistance, the councils for the rights of children and adolescents have a deliberative character and their composition is paritary among representatives of the government and civil society. Differently, however, in this case, non-governmental representatives are entities that provide child and youth protection services (CORTES, 2005, p. 156). 
The SCA began the process of effectuation of the participation councils focused on the defense of children and youth's rights. Since its implementation, the first step has been taken to comply with the precept of popular participation in the policies of assistance and care for the rights of children and adolescents, as established by FC/88 (CARDOZO, 2011).

In the same way, the National Council on the Rights of Children and Adolescents (CONANDA), instituted by Law No. 8.242/91, came into being, materializing a great advance in the process of social change, thus creating a new way of looking at the demand for the rights of Brazilian children and youth. According to Herbstrith-Willig (2004 apud CARDOZO, 2011, p. 29):

[...] the institution involved a very strong movement for the installation and implementation of the Councils for the Rights of Children and Adolescents and the Guardianship Councils, both at the state and municipal levels, since the Statute adopts the doctrine of municipalization of matters pertaining to this issue. The municipalization in the SCA reflects the exemption of the Union and the State from part of the power they had held until then in this matter. Because of its autonomy, the municipality began to practice and implement the policy of attending to the rights of children and adolescents, according to the needs of its region, with the Municipal Council for Children and Adolescents and the Guardianship Council as its main instruments.

This way, the councils created as a result of the law that instituted the SCA configure the main tools for population participation and change of mentality, because they reaffirm the constitutional maxim that it is the role of all society to ensure the protection of children and adolescents. According to the aforementioned, the SCA brings important tools for implementing social policies and creating agencies, so that the priority in assistance and zeal, brought in the text of the Magna Carta, are operated at state and municipal levels, since they are the levels of government closest to the public to be attended.

The SCA "[...] ensures that all children and adolescents, regardless of color, race or social class, are treated as citizens who need attention, protection and special care in order to develop and be healthy adults" (PARANÁ, 2010, p. 44). Initially, it outlines the rights of children and youth in relation to life, education, health, freedom, dignity, family life, sports, culture and leisure, work, and prevention of threats and violation of rights (BRASIL, 1990, art. 1-85), as well as listing the principles that guide the application of these rights. It also makes clear that children and adolescents are a priority in the development of public health, assistance, education, and protection policies.

From articles 86 to 267, the SCA addresses the rules to be used to correct deviations, and/or to have access to the Brazilian State, without abuse or omission of the guarantees of these rights (PARANÁ, 2010, p. 44). Article 86 describes the model of care and realization of social policies for children and youth, determining the lines of action and, in general, the design of public policies. Article 88 also cites and sets guidelines for the development of policies to assist children and adolescents (BRASIL, 1990).

The two councils cited in the SCA have defined roles concerning social assistance policies. The CONANDA (s.d.) is constituted by "[...] deliberative bodies responsible for ensuring, in the Union, states and municipalities, priority for childhood and adolescence [...] the councils formulate and oversee the implementation of public policies to assist childhood and adolescence. They act in the registration and coordination of assistance and protection policies, as well as in overseeing the compliance with legislation that ensures the human rights of children and adolescents:

[...] constituted, on an paritarian basis, by representatives of the government and civil society, the councils are administratively linked to the government of the state or municipality, but have autonomy to guide their work and to activate Guardianship Councils, the Special Protection Delegacies and the instances of the Judiciary, such as the Public Ministry, the Public Defenders' Offices and the Special Courts for Children and Youth, which make up the network for the protection of the rights of children and adolescents (PARANÁ, 2010, p. 23).

The Guardianship Council is the "[...] body in charge of the society, through the vote, to watch over the fulfillment of the duties and rights of the child and adolescent" (PARANÁ, 2010, p. 7), acting in the direct assistance of the child and adolescent and in the inspection of social policies. The Guardianship Council operates as an executive body and, at the same time, an intermediary body between all the links of the protection network, such as health posts (health policy), schools (education); in its supervisory role, it acts together with the Public Ministry and the State Justice. 


\section{The Guardianship Council and the Street Bureaucrats}

Having arisen with the edition of the SCA, and according to its article 131, the Guardianship Council is an autonomous, non-jurisdictional body. The referred article also disposes, in a general way, of the finality of the Council, that is, to zeal for the protection and effectuation of the rights of children and adolescents.

The Guardianship Council is a permanent body, i.e., "[...] once it has been created by municipal law, it can no longer be deconstituted" (ROSÁRIO, 2002, p. 18). For the functioning of the body, there will be at least five guardianship councilors in each municipality to be chosen by the community for a 3-year term, with the possibility of reappointment. In order to run for guardianship councilor, the candidate must necessarily have recognized moral idoneousness, be over twenty-one years of age, and reside in the municipality to which he/she applied (BRASIL, 1990, art. 133). However, "[...] municipal law may establish more restrictive criteria such as higher education, prior approval in a knowledge examination or participation in a previous formation course" (MARTINS and CUSTÓDIO, 2018, p. 3). The implementation of a Guardianship Council is mandatory in each Brazilian municipality, and the Municipal Law that institutes the agency may foresee the creation of more Councils, or microregions, to better serve the infant-juvenile public. Resolution No. 75 of CONANDA recommends that there be a Guardianship Council for each group of 200.000 inhabitants.

The SCA is the general legislation that regulates the measures, and the procedure of action regarding the assistance measures must be regulated and determined by edited municipal legislation. In general, the Municipal Laws provide for procedures to perform and request diligences, visits to places for inspection, as well as visits to places and residences, in order to ensure the protection of rights. It is important to point out that the Guardianship Council has a peculiar characteristic, since it has executive power, absent in all other types of councils in Brazil. That is, even being a council, it has a very distinct characteristic from the others, which is, the power to execute measures that it finds fit within its legitimacy and its legal attributions defined by the SCA and the respective Municipal Law.

The rights to be protected by the Guardianship Council in its performance are described in article 227 of the FC/88 and again affirmed by article 4 of the SCA, which states that "[...] it is the duty of the family, the community, society in general and the public power to ensure, with absolute priority, the realization of rights regarding life, health, food, education, sports, leisure, professionalization, culture, dignity, respect, freedom and family and community coexistence" (BRASIL, 1990, art. 4).

The Guardianship Council acts as a mediator and fiscalizer of the rights and policies of assistance to children and adolescents, constituting a body that provides a closeness between society and the State. In this context, the councilors can be analyzed based on the theory of bureaucracy at street-level, formulated by Lipsky (1980). The "bureaucrats at the street-level" are those officials "who interact directly with citizens in the course of their jobs, and who have substantial discretion in the execution of their work (LIPSKY, 2010, p. 3). In this denomination, according to Lotta (2014), police officers, teachers, health agents, social workers, inspectors, among others, who work directly with the beneficiaries of public policies, can be included. Their actions, during implementation, are extremely relevant, once "[...] the decisions of street-level bureaucrats, the routines they establish, and the devices they invent to cope with uncertainties and work pressures, effectively become the public policies they carry out (LIPSKY, 2010, p. xiii).

In public policies for the protection of children and youth, the guardianship councilors are the bureaucrats at street-level. They can be considered the "spearhead" of these actions, due to their direct relationship with the user and considerable influence on the quality of the policy. This influence manifests itself, among other elements, in the beliefs, values and experiences of the implementers, since "[...] the ideas and values of the implementers, in an interdependent manner, influence the conformation of the path of public policy and its results" (LIMA and D'ASCENZI, 2013, p. 16).

It is the responsibility of the Guardianship Council: the inspection of assistance entities responsible for the execution of protection and socioeducational programs, both governmental and non-governmental, instituting judicial proceedings to inquire irregularities in these entities, when necessary; instauration of procedure to inquire administrative infraction to the norms of protection of children and adolescents; assistance to children and adolescents whose rights are under threat or injured; assistance to the child who has committed an infraction; assistance to parents or legal guardians; promoting the execution of their decisions; and the execution of a protection measure to the adolescent offender (MINISTÉRIO PÚBLICO DO PARANÁ, s. d.).

The Council is competent to work together with the jurisdictional bodies, both in the prevention of rights violations, holding lectures and guiding the population, as well as in the forwarding of judicial measures that are beyond its competence. 
Among its attributions are: requesting, notifying, forwarding and applying necessary measures for the assistance of children and adolescents together with their families. This way, the Guardianship Council acts as an articulator of the most diverse demands of the infant and juvenile population, which come to it through both denouncements and the search of the family or those responsible. This way, it acts executively or mediates between children and adolescents and their families and the state agencies that execute the public policies of assistance.

The relationship between the Guardianship Council and the school is likewise given. The school forwards complaints about violations (when they occur outside of the it or in a situation of school evasion), where the Council acts as a mediator between the family or those responsible, and the school tries to solve the problem and guarantee the right to education to the child or adolescent. In other circumstances, the Council has the legitimacy to forward cases to the Judiciary, both to the Public Ministry and to the State Courts. An example of this situation is the need to initiate actions to request access to the health system and denounce crimes against life, as well as cases of mistreatment and more serious violations of rights.

A particularity of the guardianship councilors is that, even though they are bureaucrats at the street level, they do not suffer pressure from the State as to the effectuation of the policies they execute. This happens because the Guardianship Council is an autonomous body, not subordinated to any other body, linked only to the Executive Power (ROSÁRIO, 2002). In addition, because they are elected, the councilors suffer the classic pressure of electoral democracy. According to Cantalice, Nevertheless(...)

[...] to figure as a direct election, the prerogative of autonomy and political legitimacy, both during the process and in the actions of their respective elected representatives, have not been consolidated. Given that, in a broad and blunt way, the protected action of its members is observed, through direct and indirect interference of political parties, congressmen, churches, the State and even the private initiative, which dictate rules and actions in the Councils, whose aims are aligned with the reproduction and assistance of the interests they represent, in detriment of the actions turned to the demandability of the rights of children and adolescents foreseen in the pertinent legislations to this area (CANTALICE, 2011, p. 49).

Therefore, given the choice of councilors via community elections, it often resembles "[...] a party-political dispute along the lines of the general elections of the Brazilian representative political system" (PAIVA, 2011, p. 126). A context in which the financial condition for financing the campaign can influence the outcome of the process, and not only the candidate's trajectory of struggle and his/her interaction with society. Allied to this, the chosen candidate may not be the most active and committed, but the most articulate and charismatic. Moreover, the position of guardianship councilor often serves as a political-electoral springboard, since the Council becomes a great showcase for future political office in the legislative and municipal executive spheres.

The precarious conditions of the places where most of the councilors carry out their activities must also be considered. In other words, "[...] they do not have an adequate place to meet the demands, sometimes they share the same physical space with other organs; they do not have a telephone, internet access and transportation; and, also, they do not have social equipment from the child and adolescent protection network - such as a foster home, passage, shelter, among others" (CANTALICE, 2011 , p. 48). These situations can directly interfere with the implementation of public policies and the handling of issues of protection of the rights of children and adolescents. This means that only advanced legislation to protect children's rights is not enough to implement public policies that ensure the effectiveness of this protection. Policy enforcers play a key role and therefore need to be valued, trained and equipped to qualify their work.

\section{The Pelotas/RS Guardianship Council}

The municipality of Pelotas is located in the southern region of the State of Rio Grande do Sul, extending for 1,610.10 km², and has, according to IBGE (2010), 328,275 inhabitants. Its Guardianship Council was established by Municipal Law No. 4.838 of July 27,2002 , which created 15 positions of guardianship councilor, three microregions, allocating five councilors in each of them. The law also provides for the creation of corregedoria (roughly translated as inspector general's office) and coordinatorship of the Guardianship Council with powers of inspection and data surveying for the State Council for Children and Adolescents. In 2010, with the edition of Municipal Law No. 5.775 of September 31, 2010, the positions of guardianship councilor were increased to 20. Finally, concerning the legal basis for the Guardianship Council in Pelotas/RS, Law No. 6.341 of April 3, 2016 created two more microregions, with six positions each, totaling 30 guardianship councilors in the municipality. 
To run for the position of guardianship councilor, the candidate must have: recognized moral idoneousness, age equal to or above 21 years at the time of taking office, residence in Pelotas, "[...] complete elementary education; psychological evaluation attesting to the capacity for work, issued by a psychologist; be aware of the characteristics of the work regime with exclusive dedication" (PELOTAS, 2019).

The selection process for the Pelotas/RS Guardianship Council is composed of two phases: the first, an objective, eliminatory exam; and the second, an electoral plea, in which those approved in the first one participate. The vote is optional and secret, all voters of the municipality can participate in the process (PELOTAS, 2019), which is supervised by the Public Ministry and the Electoral Justice. The objective test of specific knowledge is a differential in the selection of candidates in Pelotas due to its eliminatory nature, since it seeks to select, among the candidates, those who have technical knowledge for the investiture in the position.

In order to assess the legal attributions of the Guardianship Council in relation to the daily life lived by the councilors in Pelotas/RS, in-depth interviews were conducted with 12 (twelve) councilors. Of the councilors from the period 2016-2019, $50 \%$ are between 25 and 45 years old. Ten interviewees have incomplete or ongoing higher education, in undergraduate courses, pedagogy, history, geography and law. There are also councilors with elementary and high school education.

In response to the question about the motivation for the Guardianship Council, the majority answered that, before carrying out the selection process for the position, they had already had some contact with community work: some had done voluntary work with children and adolescents, others, as health agents, that is, some type of social work, not necessarily remunerated.

As for the objectives of the work, the guardianship councilors are unanimous in stating that it is a question of guaranteeing the rights of children and adolescents and acting to prevent or resolve violations of these rights. Within these objectives, there is also: the guarantee of the right to health, as they make the requests and referrals to public health policies; the guarantee of human rights, since the Guardianship Council has the legitimacy to intervene in cases of denunciation of crimes against the life and physical integrity of children and adolescents, as well as to protection from the most diverse violations. This consensus communicates with the main objective of the body that represents the guarantee and zeal for the rights of children and youth, as established by law.

As for the instruments available to achieve the agency's objectives, the advisors are much less optimistic. The interviewees affirm that the council has great difficulty in reaching its objectives, due to the failures in the child and adolescent assistance network, that is, the other institutions of the system cannot adequately attend when demanded.

Thinking about the difficulty of achieving the objectives of the Guardianship Councils, we return, here, to the street-level bureaucrats who, despite having their importance made secondary several times, can cause great impacts; many times, negative. For example, the absence of specialties strongly limits the work of the Council, which leads to the decharacterization of the policy format. Another limiting aspect is the difficulty of informatizing the protection network, which would speed up the request for documents and services.

Regarding the motivation for the Council's action, the interviewees were unanimous in informing that they act through provocation, that is, they basically react to the denunciations. Generally, there is no proactivity and/or preventive work on the part of the councilors; when they develop initiatives of this type, they are personal and individual, which demonstrates that the discretionality of this public servant (street-level bureaucrat) is very little limited.

The 'modus operandi' of the Guardianship Council is, normally, given in the following way: the complaint is received anonymously, or by schools, hospitals and other agencies that have the legal duty to inform any indication of violation of the rights of children or adolescents. Then, according to the case, the councilors take the necessary steps. In more serious reports, such as alleged crimes against physical integrity, the protocol is to go to the place and find out the origin to inform the Public Ministry. Facing the executive power, the Guardianship Council, in extreme cases, removes the child from the hostile environment or even determines the immediate withdrawal of the alleged abuser.

The research clearly revealed the role of the Guardianship Council as an articulator between children, adolescents and family and the public policies offered by the State. However, the Council acts as an "emergency room," where families go in search of solutions to the most diverse problems, even some that do not fall within the council's competence. 
Regarding the most frequent types of assistance, the survey revealed strong geographical distinctions in the microregions responsible for downtown assistance, where the most frequent cases are related to family conflicts, drug abuse, physical and sexual abuse, and school evasion. In the most remote regions of the center, such as the Z3 Fishermen's Colony, the most frequent cases are related to child labor and marriages of adolescents under the age of 14 .

Concerning the solution of the cases, the councilors reaffirm the duty of articulating the services with the assistance network, which public policies of health, education and assistance in the city of Pelotas/RS are often flawed. Structural problems also contribute to the unsuccessful solution of the cases, since basic inputs are lacking, such as equipped service rooms, office materials, and, mainly, an information system that connects the social protection network. Many councilors use work material purchased with personal resources, which is completely unacceptable for the public service.

The link between society and the State to promote the protection of the rights of children and adolescents, as demonstrated during the research, is made by the Guardianship Council. However, many times, the service necessary to solve the demand is not made available by the municipality or is provided in a scarce manner, making it difficult to solve the cases and guarantee the rights.

\section{FINAL CONSIDERATIONS}

The Guardianship Council has a very particular constitution, since it is legally autonomous, not subordinated to another agency, solely linked to the Executive Power. The main attributions of the Guardianship Council are those legally established by the SCA, which fundamental principle is to guarantee and watch over the rights of children and adolescents acting as an articulator between society and the State. It acts as a link between the organs that make up the network of protection of children and adolescents. The Guardianship Council is the "spearhead" of public policies.

In the municipality of Pelotas, the Guardianship Council acts in a similar way to a large "emergency room", performing the screening so that children and adolescents can have access to public policies and can be protected when victims of any abuse or crime.

Councilors can considerably influence the quality of implemented policies. This influence can manifest itself in the beliefs, values and experiences of the implementers or, also, because of the councilor's acting in favor of individual, private, partisan or group interests, to the detriment of collective demands. In addition, the ineffective functioning of the service network often hinders the protection of rights, since many services are not made available by the municipality or are made available in an inadequate or insufficient manner.

The Guardianship Council acts almost exclusively by provocation; that is, when the cases arrive by means of denouncements. From then on, the councilors start their work by sorting the case, requesting services, investigating the denunciation in loco or activating the Public Prosecutor's Office. The Guardianship Councilors articulate and connect society to public policies. Finally, the agency watches over rights, helps make them effective, and also oversees other agencies.

The peculiarity of the selection process for the Guardianship Council, of which the second phase is made up of an election, is a hindrance to its proper functioning, since, many times, the Guardianship Councils become "featherbedding" for some politicians, which contaminates the work, after all, one of its legal functions is to supervise municipal public bodies and policies. Moreover, the position of guardianship councilor often serves as a political-electoral springboard because of its public visibility.

The results found are quite promising, since they indicate that the election of guardianship councilors contributes to the effectiveness and quality of public policy, but the selection format seems limited for the same reasons of the Brazilian proportional representative system, i.e., those elected are not the most capable, committed or representative of the protection entities, but those who better articulate the electoral capital.

This research has partially confirmed the initial hypothesis that the Guardianship Council is a protagonist in the protection of the rights of children and adolescents when parents and relatives are absent or omitted. However, it is unable to effectively resolve all cases due to the isolation and fragmentation of the protection system and, also, because of the reactive stance of councilors and the lack of infrastructure at work. 


\section{REFERENCES}

BRASIL. Constituição da República Federativa do Brasil. Brasília, DF: Senado Federal: 1988.

BRASIL. Decreto no 1.302, de 4 de novembro de 1994. Aprova o Estatuto e o Quadro Demonstrativo de Cargos em Comissão e Funções de Confiança da Fundação Centro Brasileiro para a Infância e Adolescência - CBIA. 1994. Available at: <http://www.planalto. gov.br/ccivil_03/decreto/1990-1994/D1302.htm>. Accessed on: 03 out. 2019.

BRASIL. Lei no 8.069, de 13 de julho de 1990. Dispõe sobre o Estatuto da Criança e do Adolescente e dá outras providências. 1990. Available at: <http://www.planalto.gov.br/ccivil_03/leis/L8069Compilado. htm>. Accessed on: 26 out. 2020.

BRASIL. Lei no 8.242, de 12 de outubro de 1991. Cria o Conselho Nacional dos Direitos da Criança e do Adolescente (Conanda) e dá outras providências. 1991. Available at: <http:// http://www.planalto. gov.br/ccivil_03/leis/l8242.htm>. Accessed on: Oct. 26, 2020.

CANTALICE, L. B. A produção do conhecimento em torno dos Conselhos Tutelares: uma análise de teses e dissertações. In: SOUZA FILHO, R.; SANTOS, B. R.; DURIGUETTO, M. L. (Orgs.). Conselhos Tutelares: desafios teóricos e práticos da garantia de direitos da criança e do adolescente. Juiz de Fora, Ed: UFJF, 2011.

CARDOZO, A. Conselho Tutelar como instrumento de participação da população e de efetivação de política social de atendimento da criança e adolescente. 2011. Undergraduate thesis (Bachelor Degree in Legal and Social Sciences) - Pontifícia Universidade Católica do Rio Grande do Sul, Faculdade de Ciências Jurídicas e Sociais, Porto Alegre, 2011.

CORTES, S. M. V. Arcabouço histórico-institucional e a conformação de conselhos municipais de políticas públicas. Educar em Revista, n. 25, p. 143-174, jun. 2005.

COSTA, A. C. G. É possível mudar: a criança, o adolescente e a família na política social do município. São Paulo: Editora Malheiros, 1993a.

COSTA, A. C. G. De menor a cidadão: notas para uma história do novo direito da infância e juventude no Brasil. Editora do Senado, 1993b.

GONZÁLEZ, R. S. Criança também é gente: a trajetória brasileira na luta pelo respeito aos direitos humanos da infância e juventude. In: VIOLA, S. et al. (Orgs.). Direitos humanos - pobreza e exclusão. São Leopoldo: Adunisinos, 2000. p. 143-158.

GONZÁLEZ, R. S. Políticas públicas para a infância no Brasil: análise do processo de implementação de um novo modelo. São Paulo: Editora Lume, 2015.

LIMA, L. L.; D’ASCENZI, L. Implementação de Políticas Públicas: perspectivas analíticas. In: ENCONTRO NACIONAL DE PESQUISADORES EM GESTÃO SOCIAL, 6., 2013, São Paulo. Anais... São Paulo: ENAPEGS, 2013. Available at: <http://anaisenapegs.com.br/2012/ dmdocuments/19.pdf>. Accessed on: Oct. 26, 2020.

LIPSKY, M. Street-level bureaucracy: Dilemmas of the individual in public service. Russell Sage Foundation, 2010.

LOTTA, G. S. Agentes de implementação: uma forma de análise de políticas públicas. Cadernos Gestão Pública e Cidadania, v. 19, n. 65, jul./dez. 2014. Available at: <http://bibliotecadigital.fgv.br/ojs/index. php/cgpc/article/view/10870/40890>. Accessed on: Oct. 26, 2020.
MARTINS, M. D.; CUSTÓDIO, A. V. As atribuições dos conselhos tutelares na proteção aos direitos fundamentais da criança e adolescente. In: SEMINÁRIO INTERNACIONAL DE DIREITOS HUMANOS E SOCIEDADE, 1., 2018, Criciúma. Anais... Criciúma: Ed. UNESC, 2018. Available at: <http://periodicos.unesc.net/AnaisDirH/article/ download/4668/4275>. Accessed on: Oct. 04, 2019.

MOURA, M. B. Código de Menores à Criação do ECA: Estatuto da Criança e do Adolescente. Santa Rosa: Fundação Educacional Machado de Assis, 2016. Available at: <http://www.fema. com.br/sitenovo/wp-content/uploads/2016/09/3-C\%C3\%B3digode-Menores-\%C3\%A0-Cria\%C3\%A7\%C3\%A3o-do-Eca-\%E2\%80\%93Estatuto-da-Crian\%C3\%A7a-e-do-Adolescente.pdf>. Accessed on: Oct. 03, 2019.

MINISTÉRIO PÚBLICO DO PARANÁ. Atribuições do Conselho Tutelar. 2019. Available at: <http://www.crianca.mppr.mp.br/pagina-161. html>. Accessed on: Oct. 01, 2019.

PAIVA, A. B. Políticas de proteção à infância: o Conselho Tutelar de Ceilândia como foco de análise. In: SANTOS FILHO, R.; SANTOS, B. R.; DURIGUETTO, M. L. (Orgs.). Conselhos Tutelares: desafios teóricos e práticos da garantia de direitos da criança e do adolescente. Juiz de Fora: Ed: UFJF, 2011

PARANÁ (Estado). O Professor PDE e os desafios da escola pública paranaense: produção didático-pedagógica. Vol. 2. 2010. Available at: <http://www.diaadiaeducacao.pr.gov.br/portals/cadernospde/ pdebusca/producoes_pde/2010/2010_uel_gestao_pdp_elcy_mori. pdf $>$. Accessed on: Oct. 02, 2019.

PELOTAS (Município). Lei Municipal n. 4.838, de 27 de junho de 2002. Cria funções populares providas mediante cargos em comissão, mecanismos de controle, funcionamento e organização interna dos Conselhos Tutelares e dá outras providências. 2002. Available at: <https://www.lexml.gov.br/urn/urn:lex:br;rio. grande.sul;pelotas:municipal:lei:2002-06-27;4838>. Accessed on: Nov. 26, 2020

PELOTAS (Município). Lei Municipal n. 5.575, de 31 de dezembro de 2010. Dispõe sobre os mecanismos de controle, funcionamento e organização interna dos Conselhos Tutelares e dá outras providências. 2010. Available at: <https://leismunicipais.com.br/a/rs/p/pelotas/leiordinaria/2010/577/5775/lei-ordinaria-n-5775-2010-dispoe-sobreos-mecanismos-de-controle-funcionamento-e-organizacao-internados-conselhos-tutelares-e-da-outras-providencias>. Accessed on: Nov. 26, 2020.

PELOTAS (Município). Lei Municipal n. 6.341, de 03 de abril de 2016. Dispõe sobre a criação de microrregiões para atuação de conselheiros tutelares no município e dá outras e dá outras providências. 2016 Available at: https://sapl.pelotas.rs.leg.br/norma/2300>. Accessed on: Nov. 26, 2020.

PELOTAS (Município). Prorrogadas as inscrições à eleição de conselheiros tutelares. Pelotas. 2019. Available at: <http://www. pelotas.com.br/noticia/prorrogadas-as-inscricoes-a-eleicao-deconselheiros-tutelares>. Accessed on: Oct. 03, 2019.

ROSÁRIO, M. O Conselho Tutelar como órgão de defesa de direitos num cenário de exclusão social. In: NAHRA, C. M. L.; BRAGAGLIA, M. (Orgs.). Conselho tutelar: gênese, dinâmica e tendências. Canoas: ULBRA, 2002. 
Hemerson Luiz Pase

ORCID: https://orcid.org/0000-0002-3322-3003

Ph.D. in Political Science from the Universidade Federal do Rio Grande do Sul (UFRGS); Associate Professor at the Universidade Federal do Rio Grande (FURG), Rio Grande- RS, Brazil. E-mail: hemerson.pase@gmail.com

\section{Gabriele Padilha Cunha}

ORCID: https://orcid.org/0000-0002-6798-7394

Master in Political Science from Universidade Federal de Pelotas (UFPel), Pelotas-RS, Brazil. E-mail: gpcunha27@gmail.com

Márcia Leite Borges

ORCID: https://orcid.org/0000-0002-8609-6781

Ph.D. in Political Science from Universidade Federal Fluminense (UFF); Post-Doctoral in the Programa de Pós-Graduação em Direito e Justiça Social at Universidade Federal do Rio Grande (FURG), Rio Grande- RS, Brazil. E-mail: 1212.marcia@gmail.com

Ana Paula Dupuy Patella ORCID: https://orcid.org/0000-0002-9498-560X

Master in Law and Social Justice from Universidade Federal do Rio Grande (FURG); Ph.D. Student in Political Science at the Universidade Federal do Rio Grande do Sul (UFRGS), Porto Alegre-RS, Brazil. E-mail: anapaulapatella@gmail.com 